\title{
BALÁZS HORVÁTHY*
}

\section{After the First Lessons and Experiences - Cases Concerning Hungary before ECJ (2004-2007)}

\begin{abstract}
The essay attempts to give an overview on the cases relating to Hungary before European Court of Justice in the period between 2004-2007, which are classified into four categories. The first part of the article analyses eleven procedures concerning petitions for preliminary rulings, illustrating the bearings of the cases and pointing out the importance as well as consequences from the point of view of the Hungarian legal order. The essay refers to the fact that activity of Hungarian courts to apply preliminary ruling procedures is exceptionally high comparing with the other nine Member States acceded to EU in 2004 and in almost each cases concerned, the references were profoundly considered by the Hungarian court. The second category described in this paper includes cases, in which Hungarian individual persons participate as litigants (including the cases before Civil Service Tribunal). The experiences of these procedures on the basis of direct complaints indicate the conclusion that in several cases, the attorneys representing the plaintiff before ECJ involve not enough responsibilities to avoid bringing obviously inadmissible actions. In the third part of the paper the reader can get an insight into the cases in which the Republic of Hungary appears as litigant. Finally the fourth category embraces cases with indirect interest relating Hungary. These are referred but not deeply examined in the article.
\end{abstract}

Keywords: European Union, European law, EC law, European Court of Justice, Hungarian law, case law

\section{Introductory remarks}

With the accession of Hungary to the European Union, besides law-makers and law-applying organs, Hungarian law-seeker citizens and undertakings must take into consideration that the European Court of Justice (ECJ) bestowed with peremptory legal authority is entitled to make ultimate decisions on the interpretation and effect of EU Law. Thence, the updated monitoring of the judicial practice of the Luxembourg Court becomes indispensable and we need

* Junior research fellow, Institute for Legal Studies of the Hungarian Academy of Sciences, H-1014 Budapest, Országház u. 30; assistant professor, Széchenyi István University, Győr.

E-mail: balazs_horvathy@freemail.hu 
to expend more substantial care in cases, in which Hungarian parties are directly concerned.

It can be quoted cases with Hungarian implications in the period before our accession, as well. One of the most familiar ones was the Balog Case ( $C$ 264/98) ${ }^{1}$ also referred abroad. It was initiated by Tibor Balog, a former football player of MTK (a Hungarian League) by reason of the obligation illegally imposed on him to pay fees related to his registration to a European club.

Subsequently to our accession to the EU, the cases concerning Hungary before the ECJ will be classified into four categories. In petitions for preliminary ruling, interested parties are established in the main proceedings conducted by Hungarian judicial organs. The second category as follows includes cases, in which Hungarian individual persons participate as litigants, whereas, in the third category, the Republic of Hungary appears as litigant: either as plaintiff or defendant. Finally, the fourth category consists of cases, in which on the basis of indirect interest, the Hungarian party appears in various statuses in the proceedings, e.g., as an intervener or submitting observation. ${ }^{2}$

\section{Petitions for preliminary ruling referred by Hungarian courts}

\section{a) The role of the preliminary ruling procedure}

References for preliminary ruling under article 234 TEC guarantee the uniform application and interpretation of Community Law within the EU. If the court of a Member State applies Community Law during its proceedings, it may refer the case for preliminary ruling to the European Court of Justice. It may request

\footnotetext{
1 The documents related to the specific cases can be searched on the basis of case numbers and downloaded from the homepage of the European Court of Justice, see: www.curia.eu. After having had terminated the proceeding in the referred Balog Case, it has been cancelled in the register of ECJ, thus, the relevant facts can be found only in the print edition of the European Court Reports (ECR).

2 This last category of cases include proceedings between other parties concerned, in which the Hungarian Government participates as an intervener or has the right to submit observation. These cases will not be analysed in this essay, but with respect to the practice so far, it can be mentioned some example. The Hungarian Government participated as an intervener e.g. in the Case Commission v. Republic of France (C-304/02), and submitted observation in Tokaji I. Case (C-347/03), Suzuki Case (joined with C-23/02, C-24/02, C25/02), Bondi Case (C-341/04), Mostaza Case (C-168/05), Banca Popolare di Cremona Case (C-475/03), Vorel Case (C-437/05), Wienand Meilicke Case (C-292/04), RUMA GmbH Case (C-183/06) etc.
} 
the interpretation of the acts of Community organs and the establishment of the validity of the latter ones. In some cases, the proceeding court is obligated to have recourse to the ECJ. Whereas, the European Court of Justice can neither make decisions on the merits of the case, nor can it annul national legal norms.

Comparing with the other courts of new Member States acceding to EU in 2004, the Hungarian courts are relatively active to refer cases for preliminary ruling to ECJ. For the time being, eleven petitions have been referred to the ECJ from Hungarian judicial organs, out of which preliminary ruling has been accomplished in eight cases. Among that, there are cases referred in criminal procedures, but the 'hits' of the cases have concerned taxation issues.

\section{b) The 'fallen' of the red star: Fiasco in the first Hungarian case before ECJ}

Following the accession of Hungary to the EU, the first concluded proceedings were the Vajnai Case $(\mathrm{C}-328 / 04)^{3}$ referred by the Fővárosi Bíróság (Metropolitan Court). The Metropolitan Court initiated criminal proceedings against Mr Attila Vajnai, deputy secretary-general of the Hungarian Communist Workers' Party, on grounds of the charge of the use of totalitarian symbols. That is to say, because according to the Article 269/B. of Hungarian Criminal Code, the person who uses a symbol representing the red star (or other totalitarian symbol ${ }^{4}$ ) in public or publicly exhibits it commits a minor offence. The order for reference states that criminal proceedings were brought against Mr Vajnai for displaying on his clothing in public a five-point red star, made of cardboard with a diameter of $5 \mathrm{~cm}$, during a demonstration held in Budapest. A police officer who was on duty requested him to remove that symbol, which he agreed to do. By judgment the Pesti Központi Kerületi Bíróság (Central District Court, Pest) found Mr Vajnai guilty of having used a 'totalitarian symbol' in violation of Hungarian Criminal Code. The court decided to impose a one-year suspended sentence and ordered confiscation of the symbol. Hereupon, Mr Vajnai appealed against that judgment to the court which has made the reference for a preliminary ruling.

The referring court, Fővárosi Bíróság, addressed the question to the Luxembourg Court, whether the Criminal Code collides with the provisions of Community Law pertaining to discrimination or with other provisions. In the

3 The case was commented by Osztovics A.: Az első magyar előzetes döntéshozatali eljárás [The first Hungarian preliminary ruling case]. Európai jog, 4/5 (2004) 16-21.

${ }^{4}$ Beside the red star, the swastika, the insignia of the SS, the arrow cross, the hammer and sickle, the five-point red star or any other symbol representing one of those signs fall within this article of Hungarian Criminal Code. 
reference was cited Article 6 TEU, ${ }^{5}$ Council Directive 2000/43/EC, ${ }^{6}$ and Articles 10, 11 and 12 of the Charter of Fundamental Rights, ${ }^{7}$ as well. The court has observed that in several Member States, such as the Italian Republic, the symbol of left-wing parties is the red star or the hammer and sickle. It follows that members of Italian left-wing organisations may wear symbols of the labour movement without contravening any prohibition, whereas the Hungarian Criminal Code prohibits the use of those symbols. Therefore, the question arises whether a provision in one Member State prohibiting the use of symbols of the international labour movement on pain of criminal prosecution, whereas the display of those symbols on the territory of another Member State does not give rise to any sanction, is discriminatory.

The Advocate General did not submitted written opinion in the case, then, the ECJ terminated its proceedings with reference to an obvious lack of its jurisdiction on $6^{\text {th }}$ October, 2005. According to the brief reasoning of the order, the questions raised in the main proceedings cannot be interpolated into the frames of EC Law and the elaboration of criminal regulations is basically subject to the separate authorities of the Member States. ${ }^{8}$

Albeit the order has not mentioned because of needlessness of substantial analyse in the case, but it may be emphasized that the referring Hungarian court was at fault not only in the question of ECJ's competence. Namely, the reference was partly based on such of legal ground which is obviously incorrect and irrelevant. The judge has cited some articles of the Charter of Fundamental Rights of European Union. But the Charter had no binding force yet and regarding its not compulsory character it does not belong to the acts of the EC Law.

5 Article 6 TEU para 1: "The Union is founded on the principles of liberty, democracy, respect for human rights and fundamental freedoms, and the rule of law, principles which are common to the Member States."

${ }^{6}$ Council Directive 2000/43/EC of 29 June 2000 implementing the principle of equal treatment between persons irrespective of racial or ethnic origin. OJ L 180, 19.7. 2000. 22-26.

7 The articles of the Charter mentioned in the reference concern freedom of thought, the freedom of opinion, the freedom of speech, and right of public meeting, right of combination and assembly, as well.

8 The ECJ referred directly to the doctrine laid down in the Kremzow Case. See Case C-299/95 Kremzow ECR [1997] I-2629, paragraph 15. 
c) Reviewing the consumer protection regulation: the Hungarian Civil Code before ECJ

In the Ynos Case (C-302/04, Ynos Kft. v. János Varga), the facts were constituted by an action taken in connection with a contract of sale of real estate at the Szombathelyi Városi Bíróság (Municipal Court Szombathely). In his petition to the ECJ, the Hungarian judge requested the interpretation of some of the provisions of Council Directive 93/13/EEC on Unfair Agreement Conditions. The two related questions exposed the issue, whether a rule of a member state conforms to the respective directive, according to which an unfair agreement condition can only be considered invalid, if the consumer expressly challenged it, and according to which other parts of the agreement can only persist as valid, if it had been concluded by the parties even without the condition that has proved to be unfair. Nevertheless, the third question was by far more important: does the element that the facts of the case of the main proceedings had been established before the accession of Hungary to the EU, i.e., before $1^{\text {st }}$ May, 2004 influence the judgement of the former questions. The importance of the questions to be answered was indicated by the fact that the case was remitted to the Grand Chamber and that besides the Hungarian Government, the Commission and five other member states also made observations during the proceedings. Related to the third question, the Advocate General in his motion made on $22^{\text {nd }}$ September, 2005 referred to the fact that since Hungary had not been a member of the EU at the time of the main proceedings, i.e., in 2002, the rules of the respective directive were not relevant, consequently, the European Court of Justice did not have competence to answer the questions. In case, nevertheless, the Court did establish its competence and considered the case on the merits, the Advocate General briefly dealt with the first two questions and according to his standpoint, the quoted regulations of the member state would be contrary to the directive.

In its Judgement of $10^{\text {th }}$ January, 2006, the ECJ explicated that it was incompetent to examine the questions on their merits, since it had jurisdiction exclusively in those cases, the underlying facts of the cases of which were established following taking effect of the Accession Treaty. ${ }^{9}$ This doctrine had been consequentially adhered to by the ECJ related to former enlargements. ${ }^{10}$

9 Cf. C-321/97. Andersson and Wåkerås-Andersson, ECR [1999] I-3551, paragraph 31.

${ }^{10}$ For further comments, see Láncos, P. L.: Case note: Ynos-intertemporality and the jurisdictional jurisprudence of the ECJ. Acta Juridica Hungarica, 48/1 (2007) 87-93, Szabó P.: Az Ynos Kft.-ügyben hozott luxemburgi bírósági ítélet előzményei és utóélete - az előterjesztő magyar bíró szemével [The antecedents and the consequences of the judge- 
d) Importing cars from the inner European market: the successful attack on the registration tax

The registration tax regulation on import cars introduced after the Hungarian accession to EU was much discussed not only in the theory: several business federations, chambers etc. have heavily criticised the obviously discriminatory character of this Hungarian tax regulation. Two preliminary ruling procedures concerned this matter, which were finally joined and the ECJ passed common judgement in these cases.

Firstly, the Nádasdy Case was referred to ECJ, (C-290/05, Ákos Nádasdy v. Vám és Pénzügyörség Észak-Alföldi Regionális Parancsnoksága). After the suspension of a procedure concerning the judicial review of an administrative decision, the Hajdú-Bihar Megyei Bíróság (County Court Hajdú-Bihar) had recourse to the ECJ. The plea in law exposed the issue, whether the domestic regulation of registration tax was in accordance with EC Law. Namely, whether a kind of tax imposed on motor vehicles imported from other member states is applicable, when it ignores the value of the car and determines the amount of the tax to be paid exclusively on the basis of the technical features of the motor vehicle (engine type, engine capacity) and of its environmental classification. On the other hand, how can the circumstance in re EC Law be evaluated, that no registration tax is imposed on motor vehicles placed in circulation before taking effect of the act on registration tax in Hungary. During the proceedings, the Hungarian and Polish Governments as well as the Commission submitted observation. According to the former ones, the regulation was in accordance with Community Law and the ECJ should reject the petition, since it could not reply, so as to promote the conclusion of the main proceedings. Nevertheless, the Commission deemed the Hungarian system of registration taxes discriminative and contrary to Community Law, which was not accidental, since it had conducted a related examination vis-à-vis Hungary in so-called breach of obligation proceedings. The Advocate General brought forward his motion on $13^{\text {th }}$ July, 2006. According to his standpoint, the system of registration taxes discriminated against cars imported from other Member States vis-à-vis used cars purchased in Hungary, since no registration tax had to be paid in case of

ment of Luxembourg Court in case Ynos Kft.-from the aspect of the referring judge]. Európai jog, 4/5 (2006) 31-36, Kovács, B.-Nemessányi, Z.: Az első magyar előzetes döntéshozatali eljárás margójára: a közösségi jog visszaható hatályának és a Dzodzi-elv alkalmazhatóságának kérdése [To the margin of the first Hungarian preliminary ruling case: the question of the retroactive for of Community Law and the application of doctrine 'Dodzi']. Európai jog, 1 (2006) 3-11. 
purchases in Hungary. Furthermore, the registration tax was not proportionate to the value, since it was not adjusted to the age of the vehicle, this, however, pertained merely to the period examined during the proceedings, since the respective rule was amended as of $1^{\text {st }}$ January, 2006.

The other case regarding registration tax was the Németh Case (C-333/05), Ilona Németh v. Vám és Pénzügyörség Dél-Alföldi Regionális Parancsnoksága). As mentioned before, was lodged independently from the case above, but its subject-matter was similar, therefore the ECJ has jointed the two cases. The Német Case was initiated before the Bács-Kiskun Megyei Bíróság (County Court Bács-Kiskun). The court addressed four questions to the European Court of Justice. The first two questions focused on the issue, whether a tax imposed by a member state, such as the Hungarian registration tax may be considered to be a customs duty or a measure having an equivalent effect, or, if it cannot, can it be considered to be a type of import duty. If the former questions are answered in the negative, the third and fourth questions combined were directed at the issue, whether the domestic registration tax can be considered to be in conformity with Community rules. The Advocate General proceeding in the Nádasdy Case made a motion in this case, as well. According to his standpoint, the registration tax can by no means be considered a customs duty, since it was not imposed related to border-crossing, but by reason of the registration of motor vehicles in the territory of a specific member state. The logic of his final conclusion more or less coincided with his opinion explicated in the Nádasdy Case, scilicet, the registration tax was merely admissible in a member state, on condition that it was applied without differentiation, i.e., discrimination.

It was expectable on the basis of the former adjudicational practice of the European Court of Justice, that if it accepted the standpoint of the Advocate General, the Hungarian State would have to reimburse those entitled the amount of the registration tax collected pursuant to the regulation effective between May, 2004 and December, 2005. On the basis of the Judgement of the ECJ pronounced on $5^{\text {th }}$ October, 2006, the registration tax was contrary to EC Law, so far as it imposed a higher amount of tax on used imported cars, than on used cars already registered in Hungary. In other words, the registration tax was contrary to Community Law, so far as its amount was calculated without taking the depreciation of the vehicles into account, in such a way that when applied to used vehicles imported from other member states, it exceeded the amount of the tax included in the residual value of similar used vehicles which have already been registered in the member state of importation. ${ }^{11}$

\footnotetext{
${ }^{11}$ For the cases concerning Hungarian registration tax, see: Simon, D.: Taxation de l'immatriculation des véhicules automobiles. Europe, 2006 Décembre Comm. nº 367.
} 
e) Controversy on compatibility of local business tax with EC Law

Not only registration tax, but the Hungarian local business tax (HIPA) has given rise to much controversy. The first case referred to ECJ was the Lakép Case (C-261/05, Lakép Kft., Pár-Bau Kft., Rottelma Kft. v. Komárom-Esztergom Megyei Közigazgatási Hivatal) which was taken related to judicial review of administrative decision to impose local business tax by tax authority. In its petition for preliminary ruling, the referring court requested the construction of specific rules of the so-called Sixth Tax Law Directive (Council Directive no. 77/388/EEC). It expected an answer to the question, according to which conditions a kind of tax qualifies as sales tax, or, whether only one kind of sales tax was admissible. The essential question in this case was also the third one, since the main proceedings dealt with tax obligations deriving from legal relations established before our accession to the EU. Consequently, it was questionable, whether a retrospective calculation of taxes on the basis of tax obligations established in the period before the accession was admissible, if in the period before the accession a member state had applied two or more kinds of sales tax. With reference to its ruling on the above-mentioned Ynos Case, the European Court of Justice declared the lack of its competence on $9^{\text {th }}$ February, 2006, since it had competence to construe Council Directives in new member states exclusively as of the date of accession. Whereas, the taxes contested in the main proceedings had been imposed in the period before the EU membership of Hungary. ${ }^{12}$

In the second case relating to local business tax was the Kögáz Case (C283/06, Kögáz Rt. és tsai v. Zala Megyei Közigazgatási Hivatal), which was later joined with OTP Garancia Case (C-312/06, OTP Garancia Biztositó Rt. v. Vas Megyei Közigazgatási Hivatal). Contrast with the Lakép Case analysed

20-21, Domahidi Á.: Ungarische Zulassungssteuer für Pkw gemeinschaftswidrig. Europäische. Zeitschrift für Wirtschaftsrecht, 2007. 127-128, Adobati, E.: Diritto comunitario e degli scambi internazionali. 2006. 758-759, Anon.: Az Európai Közösségek Bírósága 2006. október 5-én, a C-290/05. és a C-333/05. számú egyesített Nádasdi Ákos kontra Vám- és Pénzügyőrség Észak-Alföldi Regionális Parancsnoksága ügyekben hozott ítélete [Judgement of ECJ in the joined cases C-290/05 and C-333/05 Ákos Nádasdi versus Vám- és Pénzügyőrség Észak-Alföldi Regionális Parancsnoksága on 5 October 2006]. Európai jog, 6 (2006) 38-45, Vincze A.: Széljegyzetek a regisztráció adóhoz közösségi jogi nézőpontból [Marginal notes to the registration tax from a Community Law's perspective]. Európai Jog, 4/5 (2004) 3-9.

${ }^{12}$ See: Anon: Az Európai Közösségek Bírósága 2006. február 9-én, a C-261/05. számú Lakép Kft. ügyben hozott végzése [Judgement of ECJ in the case C-261/05 Lakép Kft. on 9 February 2006]. Európai jog, 6/2 (2006) 44-46. 
above, a feature of the /Kögáz Case was that it did not concern an obligation obtaining before the accession, but taxes imposed following $1^{\text {st }}$ May, 2004. After suspending its proceedings, the Zala Megyei Bíróság (County Court) had recourse to the European Court of Justice. The first question exposed the issue, whether the provision of our Accession Treaty, according to which Hungary may maintain local business tax allowances to an extent of at most 2 per cent of the tax base until $31^{\text {st }}$ December, 2007 can be interpreted as a provisional exemption from the maintenance of the local business tax or the possibility of the maintenance of the local business tax allowances implies the further applicability of the local business tax. In case of a negative answer to the first question or more exactly, to the two partial questions, the County Court seeks answer to the question, whether according to the correct interpretation of the Sixth Tax Law Directive, according to which criteria can a kind of tax "qualify as not a kind of turnover tax".

The case joined to Kögáz Case has arrived from the Hungarian Supreme Court. In the OTP Garancia, the Supreme Court formulated its first question in a similar manner, but logically more precisely, than the Court referring in the Kögáz Case. Accordingly, the first question concerned the issue, whether the pertaining provision of our Accession Treaty concerning allowances in the local business tax can be interpreted as a provisional exemption from the maintenance of the local business tax or does that simultaneously imply that the possibility of the maintenance of local business tax allowances justifies the further maintenance of local business tax. In fact, the second question challenges the compliance of the disputed form of tax with Community Law, however, here again, the Supreme Court formulated its question more precisely: do we need to interpret the Sixth Tax Law Directive "in such a manner that it prohibits the maintenance of local business tax directed at the taxation of activities pursued with the aim of the acquisition of profit and income in the capacity of an undertaker, the main feature of which is that it is imposed on net income, so that it is reduced by the acquisition price of articles sold, by the value of certain intermediary services and by the cost of materials, that is, does such a tax with respect to this article qualify as sales tax."

Consequently, the question was whether the HIPA can be evaluated as type of VAT according to the Sixth Directive. If yes, the HIPA could be incompatible with the EC Law, because the Member States should maintain only one type of VAT in their taxation system. For this reason, the ECJ attempted to make comparison the character of HIPA to which of VAT. The ECJ regarting to this declared that the VAT is levied on individual transactions at the marketing stage and its amount is proportional to the price of the goods or 
services supplied, ${ }^{13}$ a tax such as the HIPA is, by contrast, based on the difference, calculated under accounting legislation, between the turnover linked to the goods sold or the services supplied during a fiscal period, on the one hand, and the purchase price of the goods sold, the value of the intermediary services and the costs of the materials, on the other. Since a tax such as the HIPA is therefore calculated on the basis of periodic turnover, it is not possible to determine the precise amount of that charge which may be being passed on to the client when each sale is effected or each service supplied, such that the condition that this amount should be proportional to the price charged by the taxable person is not satisfied. Moreover, the legislation on the HIPA includes, with regard to a number of situations, simplified rules, broadly based on a standard rate, for establishing the basis of assessment by reference either to the basis of another tax plus a fixed percentage (for sole traders and small agricultural producers), or to a fixed percentage of another tax (for undertakings subject to simplified business tax). The conclusion of the ECJ was that a tax such as the HIPA is not intended to be passed on to the final consumer in a way which is characteristic of VAT. It means that would not suffice to classify a tax such as the HIPA as a turnover tax within the meaning of the Sixth Directive, inasmuch as it is not levied on transactions in a manner comparable to VAT.

This standpoint declared by ECJ was not a surprise. Although in a very similar case concerning the Italian regional tax (irap) ${ }^{14}$ it was considered incompatible with Community Law by the Advocate General, but the Court was later more permissive and did not accept the opinion of the Advocate General. Consequently, the characteristics of turnover taxes is strictly interpreted in the adjudicational praxis of ECJ.

It can be mentioned two other case concerning the HIPA regulation which were not joined with Kögáz and OTP Garancia cases. In the OTP Bank Case (C-195/07, OTP Bank Rt. and Merlin Gerin Zala Kft. v. Zala Megyei Közigazgatási Hivatal), the Zala Megyei Bíróság (County Court Zala) requested preliminary ruling proceedings. Since the subject of the petition is related to the local business tax, the two questions posed by the Court fully coincide with the formerly formulated ones related to the Kögáz Case. Due to the judgement of the Kögáz Case, the referring court has revoked its reference and the case has been cancelled.

${ }^{13}$ See by analogy: Case C 475/03 Banca Popolare di Cremona [2006] ECR I 9373, paragraph 30 .

${ }^{14}$ The above referred Case C 475/03 Banca Popolare di Cremona [2006] ECR I 9373. I can be mentioned that Hungary has been concerned by this Italian Case as well, because the Government submitted observations. 
The other case in this field was the Vodafone Case (C-447/06, Vodafone Magyarország Mobil Távközlési Zrt., Innomed Medical Orvostechnikai Rt. v. Hungarian State, Budapest Föváros Képviselö-testülete, Esztergom Város Önkormányzat Képviselö-testülete). The referring court was Fövárosi Bíróság (Municipal Court). In the questions referred, the Court asked whether the norms of Act of Accession, which allowed to Hungary to apply, up to and including 31 December 2007, local business tax reductions of up to $2 \%$ of the net receipts of undertakings, granted by local government for a limited period of time on the basis of Hungarian tax law, must be interpreted as meaning that it concerns a temporary derogation which allows Hungary to maintain the complete business tax until that time. The last question was significantly interesting. The referring court in this case asked the interpretation of ECJ on the practice of Hungary's first and second-level tax authorities, which has consisted in avoiding any examination of the compatibility with Community law of the local business tax (HIPA), by suggesting to taxpayers that they amend their tax returns by means of self-revision, thus making difficult or impossible the practical application of Community law and requiring taxpayers to initiate tax proceedings with uncertain consequences. Namely, the question referred to the compatibility of this administrative practice with Article 10 TEC implying the doctrine of so called 'loyal/sincere cooperation with the Community'. ${ }^{15}$

Unfortunately, the ECJ had not opportunity to pass judgement in this case. After having registered the case, the ECJ ordered to discontinue the procedure, because the referring Court informed ECJ about the appeal of the Parties in the main proceeding against the reference to preliminary ruling. Therefore, the referring court has revoked its reference and the case has been cancelled.

\section{f) Pending cases}

Two references from Hungarian courts are actually in process. In the Cartesio Case (C-210/06, the case of Cartesio Oktató és Szolgáltató Bt. related to the registration of change) the Szegedi Ítélötábla (Court of Appeal Szeged) instituted proceedings related to the Decision of the Cégbiróság (Court of Company Registration), which had rejected the transfer of the seat of a limited partnership based in Baja to Italy. The petition for preliminary ruling propounded general

\footnotetext{
${ }^{15}$ Art 10 TEC: "Member States shall take all appropriate measures, whether general or particular, to ensure fulfilment of the obligations arising out of this Treaty or resulting from action taken by the institutions of the Community. They shall facilitate the achievement of the Community's tasks. They shall abstain from any measure which could jeopardise the attainment of the objectives of this Treaty."
} 
and specific questions. The general questions inquired into the issue, whether the Court of Appeal was entitled to refer a case of appeal against the decision of the Court of Company Registration to preliminary ruling to the European Court of Justice. On the other hand, can the Court of Appeal of Second Instance be considered a forum that proceeds in the last instance in re Community Law, scilicet, a court that is obligated to refer a case to the ECJ for preliminary ruling, if a question of interpretation arises. Finally, an interesting problem of procedural law was also exposed: can the entitlement of a court to request preliminary ruling be limited by the fact that an appeal against the decision suspending the proceedings and initiating preliminary ruling is admissible and the forum adjudging such an appeal may supervise this decision, that is, may instruct the court to continue the proceedings. The meritorious questions concerned the specific problems of the main proceedings, scilicet, whether on the basis of EC Law (the right of establishment) a company of a member state is permitted to transfer its seat into another member state and maintain its original nationality. The European Court of Justice registered the case and no further proceedings have been conducted till this time.

Concerning the meritorious question of the case, it is notable that according to the facts of the case of the main proceedings, the transfer of headquarters had not been deemed to be substantiated on grounds of the freedom to settle down in former cases in the adjudicational practice of the European Court of Justice. The transfer of seat and the maintenance of legal entity are deemed to be admissible exclusively in the framework of Community associations, such as European Company (SE, Societas Europaea) and European Economic Interest Grouping (EEIG).

The case mentioned at last in this section is connected with the EU's third pillar legislation. A reference for a preliminary ruling from the Fóvárosi Bíróság (Municipal Court) has been lodged on 7 August 2007 relating to a criminal proceedings (Katz Case, C-404/07). The question submitted by the Hungarian Court concerns the compatibility the Hungarian criminal procedure law to the Council Framework Decision 2001/220 of 15 March 2001 on the standing of victims. The dilemma is given by a controversial norm of the Hungarian criminal procedure code which defines the main rules on the so called 'supplementary private prosecution' (a person who can sustain a charges instead of a public prosecutor in certain cases, e.g. if the public prosecutor withdraw it etc.). But according to an other general norm, it is forbidden a witness who was heard in a case, to act as a prosecutor in the same case. It means, if a victim was interrogated as a witness (that is often the case), this person would not act supplementary private prosecution in the same procedure. Despite this 
Hungarian norms, the Council Framework Decision obliges the Member States to take measure on protect the rights of the victims.

\section{Direct Petitions of Hungarian Individual Persons}

\section{a) Individuals before the ECJ}

Another significant scope of proceedings conducted by the judicial forum in Luxembourg is constituted by proceedings instituted as a consequence of direct petitions. Individual persons may have recourse to the European Court of Justice with five specific types of petitions: with a view to the annulment of specific Community actions in case of direct concern, in case of institutional default, with a view to the compensation of damages incurred by the institutions of the Community and their employees during the accomplishment of their tasks, in case of legal disputes related to agreements concluded by the Community, so far as the European Court of Justice has been designated as an arbitration court, and in case of legal disputes concerning civil service between the Community and its employees.

Adjudication of the first four types of petitions is subject to the competence of the European Court of First Instance (cases registered as type "T"), whereas, in case of a petition of type 5, the Civil Service Tribunal is entitled to proceed (cases registered as type "F"). Upon the submission of direct petitions, representation by a lawyer is obligatory, appeals vis-à-vis the decisions of the Court are admissible. The following direct petitions have been submitted to the Court from Hungarian individual persons, scilicet, natural and legal entities.

\section{b) Cases obviously inadmissible}

In his action in the Szolnoki Case (T-193/05, A. Szolnoki v. Hungary), the plaintiff imputed various kinds of breaches of law to Hungary, the defendant, and requested the European Court to obligate the defendant to terminate its unlawful conduct. Before the Court could have reached a decision on the case, which would have by all means been a rejecting judgement with reference to the lack of jurisdiction, the plaintiff withdrew his petition and the case was cancelled from the register. The other case, in which the European forum had obviously no power to pass judgement, was Varga Case (T-203/05, Zsuzsanna Varga $v$. Hungary/Greece). On the basis of the action of the plaintiff, the Hungarian Court had obligated the father of the son of the plaintiff living in Greece to pay alimony. Since the implementation of this decision was thwarted 
in Greece, the plaintiff took action at the Hungarian Court against the Republic of Greece by reason of alleged defaults during the implementation of the decision above by Greek authorities. Since the latter was also ineffective, she took direct action at the European Court and requested the establishment both of the fact that both Hungary and Greece violated several provisions of international and Community law pertaining to the recognition and enforcement of decisions in civil and commercial cases and of the obligation of those to pay a specific amount of money (practically a compensation equivalent to the amount of the alimony). Under its Judgement of $18^{\text {th }}$ October, 2005, the European Court terminated its proceedings with reference to the obvious lack of its competence and to the fact that the European Court may exclusively decide on the compensation of damages incurred by Community institutions and their employees during the implementation of their duties. And finally, the third case followed by same consequences was the Tóth Case (T-153/07, Tóth v. Hungary). The case has been registered by the Court of First Instance. The complaint referred to several presumptive unlawfulness at a Hungarian university which caused injure to former student, Ms. Tóth. The proceeding is not closed yet, but its outgoing is absolutely not doubtful: the founding treaties and the Rules of Procedure of the Court do not guarantee individual persons the option of the submission of direct petitions vis-à-vis member states. In such cases, petitions are normally rejected by the Court of First Instance by reason of an obvious lack of competence. Supposedly, the Court of First Instance will order to reject this complaint.

\section{c) Annulment procedures}

The Budapesti Erömü Case (T-80/06, Budapesti Erömü v. Commission) is linked to proceedings concerning state subsidies. The plaintiff requests that the Court of First Instance annulled the decision of the European Commission to open a formal investigation procedure in the case of state subsidising of the costs of readjustment in Hungary, alternatively annul that decision, so far as it applies to the electric energy purchase agreements concluded by the plaintiff. The Commission decided on launching official proceedings concerning the contested decision on the assumed new state aid provided in the form of electric energy purchase agreements concluded between Hungarian electricity generators and the public Hungarian transmission operator. In its reasoning, the plaintiff refers primarily to a lack of competence, since according to its standpoint, it can be inferred from specific provisions of the Accession Treaty that the Commission has jurisdiction exclusively over state subsidies granted after the accession of the new member state. However, the electric energy purchase agreements had been concluded prior to accession and they are not applicable 
after the accession. For the purpose of the justification of its action, the plaintiff refers to a manifest error of law and erronious discretion. According to its viewpoint, it cannot be objectively justified that the electric energy purchase agreements of the plaintiff do contain State Aid. According to the plaintiff, the Commission failed to assess the nature of these agreements, made an inadequate assessment of the notion of economic advantage, of the notion of distortion of the competition and impact on trade. The case has not been adjudged by the Court of First Instance before the completion of the present review.

The other example to this category is the E.ON Case (T-57/07, E.ON Ruhrgas International AG and E.ON Földgáz Trade Zrt. v. Commission). In their pleas, the plaintiffs requested the partial annulment of specific documents of the European Commission proceeding as a competition authority. In a competition authority procedure, the Commission declared that the acquisition of two Hungarian gas companies by the applicant E.ON Ruhrgas International AG was compatible with the common market and the functioning of the Agreement on the European Economic Area on condition that the parties concerned complied with certain conditions and obligations. As one of the obligations, the plaintiff, E.ON Ruhrgas International AG undertook to organise and implement a gas release programme on the Hungarian market. Furthermore, the initial auction price was to be set at a definite rate of the weighted average cost of gas, so that the applicants did not suffer aggregate losses. In the contested letters, the Commission indicated that the losses made by the applicants in a given auction should be offset by any profits made by the plaintiffs in other auctions. Nevertheless, the applicants contest this and are of the opinion that losses which result from gas release auctions do not need to be offset by potential profits that may derive from future auctions. In support of their arguments, the applicants maintain that the Commission has no legal basis for increasing the financial burdens and thereby, subsequently, change the legal obligations deriving from a former related decision. Furthermore, the applicants contend that the Rules of Procedure of the Commission have been infringed, namely, neither have all the members of the Commission deliberated on the content of the two contested letters, nor has there been a proper delegation of powers to the Directorate General of the Commission. The Court of First Instance has not reached a judgement until the completion of the present review.

\section{d) Civil servants before the ECJ}

Quantifying the cases in context with Hungary in point of numbers, its considerable part concerns legal dispute civil servants belonging to the 
institutions of the EU. In the following section will be mentioned examples to this type of procedure.

The plaintiff in the Lesetár Case (T-453/04, Péter Lesetár v. European Commission) intended to undertake employment in an institution of the Community, therefore, he took written and oral entrance examinations. According to his standpoint, the evaluation of his written exam notably underevaluated his performance, furthermore, the oral exam was not adequately conducted. For that reason, he requested in his petition that the Court of First Instance changed the decision of the admissions committee, he was taken in employment and that the Court ordered the payment of his average salary for the lagging time. The Court cancelled the case from the register without conducting the proceedings. In the Tóth Case (F-107/05, Gergely Tóth v. European Commission), the plaintiff's complaint pertained to his placement on the payroll and his civil service grade as an employee. He challenged his placement with reference to his standpoint, according to which on the one hand, the substantiating Staff Regulations cannot be applied to temporary employees, on the other hand, that it violated equal treatment. He also referred to discrimination on the basis of citizenship and to the infringement of the free movement of employees, since the citizens of new member states are by all means appointed according to more unfavourable provisions. He requested his replacement and a compensation for pecuniary and non-pecuniary damages. The Civil Service Tribunal suspended the proceedings under its Ruling of $6^{\text {th }}$ April, 2006, until a decision in a similar case is passed. The plaintiff in the Borbély Case (F-126/05, Andrea Borbély v. European Commission) had been formerly employed by the Ministry of Foreign Affairs of Hungary. She was appointed for probation as an official of the European Commission. According to her petition, she had requested her employer to grant her benefits and the reimbursement of travel expenses due on various titles according to the Staff Regulations, however, the Commission rejected this. The Civil Service Tribunal, which had jurisdiction in the proceedings, partially justified the claims of the plaintiff under its Judgement of $16^{\text {th }}$ January, 2007. It considered her claim for installation allowance and daily subsistence allowance substantiated, therefore, it instructed the employer of the plaintiff, i. e., the European Commission to retrospectively compensate the plaintiff for these benefits supplemented by the amount of the interests.

Mr. Simon attempted to claim in two separate proceedings law. In the Simon I. Case (F-58/06, Balázs Dániel Simon v. Court and Commission), the plaintiff was employed by the European Court as an official being a lawyerlinguist, then he submitted an application to the European Commission for a post. The Commission selected the plaintiff for the position, who requested the Court to transfer him to the European Commission, however, the Court rejected 
the repeated requests of the plaintiff, who subsequently lodged an appeal to the Civil Service Tribunal to annul the latter decisions with reference to the deficiencies of the reasoning, obvious errors of discretion and abuse of competence. He also referred to the infringement of the principles of the protection of legitimate expectations and of non-discrimination as legal bases of the annulment. Finally, the plaintiff revoked his action, and subsequently, the Tribunal terminated the proceedings under its Judgement of $15^{\text {th }}$ March, 2007. In the second claim (Simon II. Case (F-100/06, Balázs Dániel Simon v. Court and Commission), the plaintiff requested that specific decisions of the authority entitled to the appointment were annulled, so far as they deprived the plaintiff of his rights deriving from his appointment to a probationary official (his seniority and grade), as well as of his rights deriving from the confirmation in his position. His reasoning was based on the principle of the prohibition of declining the rights secured under the Staff Regulations, the prohibition of the infringement of obtained rights and the prohibition of the abuse of authority. He explained in his petition that he did not intend to abandon the staff of officials, but wished to change his workplace and sphere of activity, thereby, he would not have lost his obtained rights. The plaintiff later revoked his action, consequently, the Tribunal terminated the proceedings under its Judgement of $15^{\text {th }}$ March, 2007 and prescribed the cancellation of the case from the register.

Lastly, one should refer to the Dálnoky Case (F-120/06, Noémi Dálnoky v. Commission). Although, in this case the plaintiff is of Romanian nationality, in her claim, she expressly refers to her Hungarian ethnic origin and mother tongue, furthermore, the subject-matter of the case is also related to that aspect, therefore, it is expedient to consider the case to have Hungarian implications. In her plea in law, the plaintiff requested that the Civil Service Tribunal annulled the notice of the European Personnel Selection Office (EPSO) for an open competition aimed at the employment of inter alia counsellors of Romanian citizenship. On the other hand, she requested that the defendant be ordered not to advertise or conduct a competition in the future, according to which the Candidate was expected to have a thorough knowledge of a specific language of the Community, but it should require the thorough knowledge of any language of the Community, disregarding the case, when the knowledge of a specific language is required with regard to the specific nature of the position to be filled. In case the competition requested to be cancelled would be conducted before the decision of the Civil Service Tribunal is passed, she requested that EPSO was obligated to eliminate all disadvantages suffered by the plaintiff or other persons concerned by reason of the discriminatory provision of the notice of the competition (e.g., announcement of a new opportunity for those, who had 
been discouraged from the submission of an application by the discriminative provision mentioned above.)

According to the plaintiff, who is of Hungarian ethnic origin and has a Hungarian mother tongue, the contested announcement violated Community Law, since it required that candidates had a thorough knowledge of Romanian. In other words, the announcement violated the right of the plaintiff to equal treatment and the prohibition of discrimination based on nationality, since Romanian citizens with Romanian mother tongue were unreasonably advantaged. Furthermore, according to the reasoning of the plaintiff, the announcement enforced discrimination on grounds of nationality prohibited under Staff Regulations and Article 12 EC, so far as a number of notices for competitions published in the past had permitted the nationals of certain member states to prove the thorough knowledge of an official language of the Community, other than the main language of the member state of which they were nationals. Furthermore, she also mentioned that the announcement of the competition included a requirement precluded under the Staff Regulations, that is, the Staff Regulations permits the prescription of the thorough knowledge of a specific language (cf. any language) of the Community as a requirement, if that is specially necessitated by the position or if that is justified by another impartial and lawful objective. Besides, in a special plea, the plaintiff requested as an interim measure that the Civil Service Tribunal suspended the contested application procedure, until a decision on her plea in the main proceedings was reached.

The Civil Service Tribunal has rejected the plaintiff's plea for interim measures under its Judgement of $14^{\text {th }}$ December, 2006. Then, on 27 September 2007 has ordered that the action of the plaintiff is manifestly inadmissible. As the most important argument, the Tribunal has referred to the too late submit of the plaintiff's claim. The Tribunal pointed out that according to the Staff Regulations, a notice of competition is an act drawn up by the appointing authority. Thus, the challenging of a notice of competition must be preceded by a complaint lodged, in accordance with the Staff Regulations, an action before the Tribunal must be brought within three months of the date of notification of the decision taken in response to the complaint. This time limit is to be extended on account of distance by a single period of 10 days. However in the present case, the Tribunal has found that, the main action was brought after the expiry of the time-limit for doing so. 


\title{
IV. The Republic of Hungary in a position of a defendant or a plaintiff
}

\author{
a) The procedures concerned
}

At the European Court of First Instance, any member state including the Republic of Hungary may take action as plaintiff related to complaints against the Commission, furthermore, in issues of state subvention and of commercial protective measures vis-à-vis the Council and in proceedings launched following petitions submitted against measures taken by the Council as an executive power. Before the European Court, member states can come up both as defendants and plaintiffs. In proceedings instituted for the purpose of the establishment of a breach of obligation by a member state, the Commission shall proceed as plaintiff vis-à-vis the Member State, disregarding the exceptional case, when in lieu of the Commission, another member state initiates proceedings by reason of a breach of obligation. As a matter of course, in such a case, the latter member state will proceed as plaintiff. Furthermore, member states may take action as plaintiffs before the European Court, if they submit a petition with a view to the annulment of an institutional action or to the establishment of an institutional default, or, in case of appeals against the Judgements of Court of First Instance.

\section{b) Criteria of the quality for maize: the first victory of Hungary}

In its first direct action, namely in the Case T-310/06 (Republic of Hungary v. Commission), the Republic of Hungary requested the partial annulment of specific rules pertaining to maize intervention affecting domestic producers expressly detrimentally. According to the reasoning of Hungary, the Commission breached the legitimate expectations of the producers by introducing during the financial year a requirement relating to the specific weight of maize. Furthermore, the Commission failed to take account of the principles of legal certainty and proportionality and the requirement of gradual adjustment, which are incompatible with the inordinately short preparatory period between the date of publication and the date of entry into force. As a conditional viewpoint, the plea of Hungary mentioned that the Commission did not have the authority to lay down the requirement relating to the specific weight of maize. In case the lack of authority cannot be justified, the plea refers to an abuse of power, scilicet, the Commission exceeded its powers, when it substantially altered the intervention regime for maize in practice, under the pretext of amending the qualitative parameters for intervention. Notwithstanding, even if the Commission was empowered to lay down the requirement relating to the specific weight of 
maize, according to the Hungarian standpoint, the Commission made a manifest error of assessment by establishing a criterion for the average quality of maize, since it did not take account of the fact that the maize produced in the Community is mainly used for fodder. We have already referred to the fact that the Commission has failed to fulfil its obligation under Article 253 EC to state the reasons on which legal acts are based and has also infringed the procedural rules of the Management Committee for Cereals in not respecting the time limit laid down by those rules.

Hungary, the applicant requested the expedition of procedures as a provisional measure, which was rejected under the Judgement of the Court of $16^{\text {th }}$ February, 2007. The Court acknowledged the argument of the applicant that the date on which the contested provisions entered into force took producers by surprise, for they had reasonably expected to have time in which to adjust to the introduction of such a novel obligation. On this too late date, the producers had no opportunity to modify their structure of production. Because of the short period of the introduction, the Hungarian producers, even if prudent and circumspect, could not, for want of prior information, reasonably have expected that the variety of maize sown and the technology used would no longer enable them to produce maize meeting the quality conditions for buying in intervention. Although farmers produce for the free market, the conditions for intervention buying nevertheless influence their financial decisions. Moreover, the Court pointed out that the Regulation of the Commission does not state clearly and expressly that the introduction of the criterion of specific weight for maize is intended, in addition to the need to ensure consistency with the rules applicable to other cereals, to upgrade the quality criteria for maize. Consequently, the explanations furnished by the Commission during the proceedings, to the effect that specific weight forms a relevant criterion of quality, do not reflect the fundamental reason for the introduction of that criterion as it appears from a close reading of the Regulation. Besides, according to the Court's decision, the Commission was not able to dispel the established contradiction, with the result that not only is its claim that specific weight reflects the nutritional value of maize not supported by any evidence but it constitutes, moreover, a manifest error of assessment in light of the only evidence available to the Court in these proceedings. After that all, the Court declared that the Regulation is vitiated by a manifest error of assessment and the claimed provisions of the Regulation relating to the criterion of specific weight for maize must be annulled. 
c) Infringement procedures against Hungary

The first case opened by the Commission was Case C-30/07 (European Commission $v$. Republic of Hungary). The proceedings were related to defaults of legal harmonisation and notification. According to the plea of the Commission, the defendant, i. e., the Republic of Hungary did not comply with its obligations deriving from Council Directive no. 2003/109/EC concerning the status of third country nationals who are long-term residents in Hungary, since it failed to adopt respective and compliant law, decrees and administrative provisions and to inform the Commission thereof. The period prescribed for the implementation of the directive in national law expired on $23^{\text {rd }}$ January, 2006. After the Hungarian Országgyülés (Parliament) have passed the required modifications of law at the close of the year 2006, the Commission revoked the claim and the ECJ ordered to cancel this case from the register.

The other infringement procedure, the Case C-148/07 (European Commission v. Republic of Hungary) was initiated by the Commission before ECJ also because of reason of the breach of obligations deriving from legal harmonisation. Namely, the Commission requested the establishment of the fact that the Hungarian law-maker, by failing to eliminate the restrictions to the provision of cable television services imposed by Para. (4) of Article 115 of Act 1 of 1996 on Radio and Television, failed to fulfil its obligations under Commission Directive no. 2002/77/EC on Competition in the Markets for Electronic Communications Networks and Services. According to the Commission, pursuant to the abovementioned law, the Republic of Hungary failed to fulfil its obligations under the above-mentioned directive by restricting the right of cable television service providers to broadcast programmes, so that in territorial coverage it is no more than one third of the population. The obligation of transposing the directive should have been fulfilled by the date of our accession to the EU, scilicet, the period prescribed for transposing the directive into national law expired on $30^{\text {th }}$ April, 2004. The default of the Hungarian legislative organs was also in this case quiet evident. Országgyülés has modified the act complained, then, the claim was revoked and the procedure terminated.

\section{Conclusion}

From the foregoing it will be seen that the embedment of the Hungarian adjudicational system in the Courts of the European Union is possibly more noteworthy than that was expected before the accession. The participation is especially outstanding in the preliminary ruling procedures. In the first three 
years period of our membership, the number of cases referred by Hungarian courts counts almost so much as which of preliminary ruling procedure referred by the other 9 Members States acceded with us in 2004 (Hungary's had 11 references, the other nine Member States had altogether 14 between 20042007). Consequently, it can be declared, that Hungarian courts refer most actively to ECJ for interpretation of EU Law within preliminary ruling procedure among the countries of the region, even if the major part of the cases described in this essay were in connection with the local business tax (5 cases) and with registration tax imposing on cars (2 cases). Generally, these preliminary ruling procedures referred by Hungarian courts were well and profoundly prepared, only one case may be regarded as an example for unconsidered reference: in Vajnai Case concerning the use of totalitarian symbols, the ECJ has not examined the substance of the case but refused the request for obvious lack of competence.

The cases relating to procedures initiated by individuals are not of importance until now but one consequence can be formulated. As the cases Varga and Szolnoki have shown the attorneys representing the individuals have significant responsibility for avoid to lodge unnecessary requests before ECJ. In these cases previously mentioned, the plaintiffs claimed for such cause of action which is unquestionably outside the jurisdiction of the ECJ (action for damages against Member States etc.). These cases cause not only superfluous work and costs for ECJ but it gives an awkward evidence of attorney's imperfect professional skills. 